\title{
Homelessness by Chris Gartner In The Pursuit Of Happiness Movie: Individual Psychological Approach
}

Fachriza Mukhlis Choirudin

Muhammadiyah University of Surakarta

Abdillah Nugroho ( $\square$ abdillah_nugroho@ums.ac.id)

Muhammadiyah University of Surakarta

\section{Research Article}

Keywords: Homelessness, Struggle, Survival

Posted Date: January 20th, 2022

DOI: https://doi.org/10.21203/rs.3.rs-1233775/v1

License: (c) (1) This work is licensed under a Creative Commons Attribution 4.0 International License.

Read Full License 


\section{Abstract}

The Pursuit of Happiness is a movie that tell about the struggles and obstacles of life. It is based on true sotry by Chris Gardner (played by Will Smith) before he get his dream job that would absolutely give him and his son (played by Jayden, Smith's son) a better financial and will allow them to walk on normal lives like the people middle class in America. The film focuses on the challenges Chris Gardner faces in achieving his goal and how he was able to achieve it. This research aims to describe about the homelessness that happened to Chris Gardner and how he can survive it until he got success. The method for this research is qualitative with descriptive approach. The main source for this research The Pursuit of Happiness movie. The data in this study is script that consist of dialogue on the movie. The result of this research show the illustrate of homelessness portrayed by Gardner.

\section{Introduction}

A movie or film is a kind of visual communication where there is a video, sound, and effect which are used to tell stories to people. All people around the world usually enjoy the movies as a type of amusement or another choice to pass their time. There are some genres in movies, such as comedy, horror, fiction, and so on. A movie also has a message to convey for the viewer.

Movies are amazing art which can create visual, audio, and effect in one creation. It is called the best irresistible shape of amusement, everything that shows on the sail people can see it like something real in life. Everything that appears on screen is just the same as what is in reality, such as people, place, nature, etc. Moreover, there is music, sound effects, and CGI technology that can make a movie more perfect.

Most movies are made to be shown in theaters and at home on the big screen TV. Movies are shown in theaters over a time weekly or month and can be promoted by various media. The producers of the movie also display it on many streams platforms. So they can see the movie without going to the theater.

Struggle means experiencing difficulties and working very hard to do something. People will give all of their effort to make what they want become real. Especially in real life, people should have these characterizations. People can try many ways to get anything they want, but one thing should be remembered is not all of them can be reached. People can see a struggle not only in real life, but also in a fictional story like a story in a novel or drama. Many stories give the main character a strong characterization to lead the struggle.

Definition of homeless is a condition of living in a home that is below the minimum standards or has no safe housing. Red Cross Victoria (2016) said that a people can be called as homeless if there are a few things below : Life on the street (particularly homeless); Switching shelters, including friends, family and shelter homes (secondary homeless); living in own dormitory without a personal bathroom and/or security of tenure (tertiary homelessness); or renting for marginal caravan park. 
Homelessness and poverty are interrelated (Red Cross (Victoria), 2016). Contrary to the common population, the homeless are more likely to have negative physical and psychological consequences. The severity of chronic illness, the incidence of respiratory and mental illness, and the use of drugs are frequently the most in homeless people than in common people. (Fazel et al., 2008). Monte Leach (2007) said that in 2005, approximately 100 million people around the world were homeless until 1 billion people (one in 6.5 at the time) were squatters, evacuee, or in while shelters, and all of them without a proper place to live.

Pursuit of Happiness is an American biographical movie which was released in 2006 with Gabriele Muccino as the director. Will Smith is the main actor and played as Chris Gardner, also his son Jaden Smith debuted as Gardner's son Christopher Jr. When Gardner writes with Quincy Troupe it will be the 2006 memoir of same name by Steven Conrad's screenplay on the best-selling. This is the same with a year of Gardner fighting his homeless. Comes from the mural that Gardner saw on the wall in front of his son's day care center, this movie title makes it unusual spelling (Pfeiffer, 2018). Columbia Pictures as the studio production on December 15, 2006 released this movie and received positive reviews. In Golden Globe and Oscar Smith got nominated for Best Actor (Littleton, 2018).

The Pursuit of Happiness tells a story about Chris Gardner as a salesperson with all his money to make an investment in portable bone density scanners. In front of clinicians he will demonstrate this machine as more practically than standard X-ray machines. These Scanners are the important thing in Gardner's life. Although Gardner can sell almost all of the machine, the deviation between the sale and all of his dependents make his financial instability and make his wife Linda estranged.

Chris Gardner get a lot of orderal as long as his life. One problem is when he got homelessness. His wife Linda left him and Christoper to work in New York because she was very frustrated with her financial on family. They don't have any much money to pay all necessary. Just because of homelessness doesn't mean the end of Chris. He never give up and start to survive to better life.

The Pursuit of Happyness is one of the boxing films and has received many Oscar nominations. This movie is about Chris Gartner as a father who becomes homelessness. Even without his wife, he keep struggle to be a good father and bring happiness to his son. According to one aspect, researchers want to examine and analyze Chris Gardner's emotions in the movie The Pursuit of Happiness, based on psychological insights. And the title is HOMELESSNESS BY CHRIS GARTNER IN THE PURSUIT OF HAPPINESS MOVIE: INDIVIDUAL PSYCHOLOGICAL APPROACH

\section{Literature Review}

There is some research related to the research written on the internet, and so far there are some researchers who have relation with the topic which deals with "individual approach". The researcher found a study on the same topic and film such as "Struggle of Chris Gardner to Get Happiness on The Pursuit of Happiness Movie: An Individual Psychological Approach" Fitriyani Fajriyatun Nufus (2009). In 
her research she analyzes how Chrish Gardner as the main character struggles to get happiness while he gets many problems of their life by psychological approach.

Another research is "Struggle for Equality in Jonathan Demme's Philadelphia movie: An Individual Psychological Approach" written by Nur Anik Bahagaiawati (2009). This research analyzes the equation scramble which is represented by Jonathan Demme's in the movie which is titled Philadelphia.

\section{Method}

The methodology provides a study with philosophies, values, assumptions, and criteria used to interpret information and draw conclusions that determine the rationale for the study. (Bailey, 1994). The methodology provides an overview that takes into account ethics, potential risks and issues, and the limitations of each approach. (Dawson, 2002). Qualitative research focuses on investigating and understanding "... the importance of an individual or group due to social or human problems."(Creswell, 2014). Qualitative methods are commonly referred to as inductive, and social construct is a reality of basic assumption. There is difficulty to intertwine, measure and complex in the variables. Consist of an internal point of view there is a priority of the topic for the data collection consists of an internal point of view (Rovai, A. P., Baker, J.D., \& Ponton, 2014)

For this research, the researcher used a qualitative method which the object of this study is the Pursuit of Happiness movie. The data in this study is a script that consists of dialogue on the movie. The researcher collects two data sources, primary and secondary data. The primary data is absolutely the movie "Pursuit of Happiness", and the secondary data source consists of other data such as the author's biography, literature, especially sociology books, internet search data.

\section{Discussion}

Homelessness is a sociological problem represented by strength and creativity in "The Pursuit of Happiness" movie that tells the inspiring story of Chris Gardner starring Will Smith. This film oscillate the lives of Chris Gardner and also Christopher as his son. Christopher starred by Jaden Christopher Syre Smith and they together keep moving from place to another place and feeling uncertain about where to go. In YouTube there are a video show interview with Chris Gardner, he said that they have to choose whether prefer to eat or have a comfortable place to stay, and finally they chose to eat and they living in non permanent place, during the time of their lives.

Given the difficulties in classifying the homeless and homeless, estimates from Homeless Coalition National in 2002 (Shi, L. \& Singh, 2004) estimate about 3.5 million people out of a total of homeless.. It is make 26 million approximately people are predicted homeless at several point in their lives, with most of these people living in cities areas.

Homelessness cannot be linked simply like the shortage of a roof under where a person can stay. It has some effects make an affect to other aspects of the personality. This is related about what the said of Bell, P., Greene, T., Fisher, J., and Baum, (2005) homelessness is synonymous with "loss of security and 
social or economic support" (on page 346). It is because the uncertainty created by the endurance of a home. This is more than just bereave the structure, it's also a fixed address-related stuff. Since the durability of the address, nowadays there are several options like for service provision may accept conformity and traceability. Also, the name of "home" is lost among those who describe themselves as homeless. In the several ways, the dilemma of homelessness can be felt by the role of the social worker. The social worker has a responsibility to conform with convenient social institution and deliver about the condition of person related to the medical sector of homeless people (Gillig, P. M. \& McQuistion, 2006)

\section{Finding the Stressors, Implement of Overcome, and Social Acceptance in movie}

There are various life stressors, implements of overcome and social acceptance found in Pursuit of Happiness movie in relation to the social problem of homelessness. There is a storyline in the movie, it completes the matter and spotlights some drawings of Chris Gardner and his son. It became necessary to take into consideration these parts in the narration so as to realize the real life moment based on the point view of Chris Gardner. Also it gives an intimate and basic experience which allows the viewer to critically comprehend about the reality based on their way from one point to another.

\section{Stressors}

Origin of stress as a father and also his son are complicated such as they have to compete for residence with many people, segregation between Chris and his wife Linda, and choosing fundamental needs.

Foremost, Chris and his son Christoper are forced to contend between them and others in order to survival, and they have incorporated this into their daily lives. The problems begin to accumulate in the early parts of the story and become worse with later events. Start from the problem of housing, the transition for his father and son is the problems which they have to pay a rent house and the next problem is where they will to stay. Gardner and his son live everyday, they have plan for meet in the next day. In this situation, they seemed like a hundreds of people at same, if not worse, desperate situation in need of affordable housing. Based on this view, a people who be a social worker can discover in order to decrease the impact of losing fundamental requirement. For this purpose, it can be finished by make a negoisation with financial resources.

Second, the separation between Chris and his wife's also has an involvement for the breakdown of their family. Although Chris can be both a mother and a father for his son, it still makes a different situation as losing one of the family's members. The separation makes something worse, even though they have worked together to reach the goal of life for their children as they want, but ultimately paid off for Chris. Regarding homelessness, ability to pay bills worsened because one of the sources of income was gone, for Chris and his son the outlook worsened as they struggled to find the extra income.

Third, when prioritizing, Chris must decide which of the three basic needs to address first. Although these three are important to living a dignified life, actually in urban communities it is very difficult where people 
should enforce to prefer being the first of the three components.

\section{Implement of Overcome}

Implement of overcome defined as the process of intrapsychic subconscious that serve to relieve emotional conflicts and states of anxiety. There are implement of overcome that should be highlighted, among others, observed throughout the movie. It was called the "fantasy defense" which became real when someone enters into an imaginary that absolutely different from real life. It especially can see in the scene where Chris has no other choice to make his son sleep in bathroom of subway station, helped with using their imagination to clear up that they believe dinosaurs was exist. When they lulled from it, they spend the night at the bathroom.

\section{Social Acceptance}

When Chris and his son wrestle with homelessness, they have the opportunity to provide temporary relief, including the existence of temporary shelters and cheap overnight accommodations. However, this is still considered in the context of homelessness. Another empowered source of social support is from the Church, which offers charity meals to help them recover from the responsibility of buying food.

\section{Conclusion}

The Pursuit of Happiness is a movie which should be recommended for everyone. Chris Gardner as the representative of this film brings a lot of moral value that is shown to the viewer. He proves that everytime he gets tempted, giving up is not the best choice. Homelessness may become the big problem that he gets, but he always knows what he should do and resolve them. From stressors, coping mechanism, and social support resources. The main point is that he keeps his mental health as good as possible, because not many people are suffering from this condition.

\section{References}

1. Bailey, K. (1994). Methods of Social Research (4th ed). The Free Press.

2. Bell, P., Greene, T., Fisher, J., \& Baum, A. (2005). Environmental psychology (5th ed.). Harcourt College Publishers.

3. Creswell, J. (2014). Research Design: Qualitative, Quantitative and Mixed Methods Approaches (4th ed.). Sage Publications Ltd.

4. Dawson, C. (2002). Practical Research Methods: A User-friendly Guide to Mastering Research Techniques and Projects. Oxford.

5. Fazel, S., Khosla, V., Doll, H., \& Geddes, J. (2008). The prevalence of mental disorders among the homeless in Western countries: Systematic review and meta-regression analysis. PLoS Medicine, 5(12), 1670-1681. https://doi.org/10.1371/journal.pmed.0050225

6. Gillig, P. M. \& McQuistion, H. (2006). Clinical guide to the treatment of the mentally ill homeless person. American Psychiatric Publishing, Inc. 
7. Littleton, C. (2018, August 30). Will Smith Says He Won't Attend Oscars.

8. Monte Leach. (2017). roof is not enough.

9. Pfeiffer, A. (2018). "The Pursuit of Happyness" - A Hollywood Interpretation Of How To Achieve The American Dream. https://wikimili.com/en/The_Pursuit_of_Happyness\#cite_ref-2

10. Red Cross (Victoria). (2016). Climate change, Housing and Homelessness - Report on the homelessness and climate change forum.

11. Rovai, A. P., Baker, J.D., \& Ponton, M. K. (2014). Social Science Research Design and Statistics. Watertree Press LLC.

12. Shi, L. \& Singh, D. (2004). Delivering health care in America: A systems approach. (3rd ed.). Jones and Bartlett Publishers. 